\title{
Cleaning Up Our Act: Systems Engineering to Promote Business Model Innovation for the Offshore Exploration and Production Supply Chain Operations
}

\author{
Karen V. Czachorowski iD
}

check for updates

Citation: Czachorowski, K.V. Cleaning Up Our Act: Systems Engineering to Promote Business Model Innovation for the Offshore Exploration and Production Supply Chain Operations. Sustainability 2021, 13, 2113. https://doi.org/10.3390/ su13042113

Academic Editor: Cecilia Haskins

Received: 18 January 2021

Accepted: 9 February 2021

Published: 16 February 2021

Publisher's Note: MDPI stays neutral with regard to jurisdictional claims in published maps and institutional affiliations.

Copyright: (C) 2021 by the author. Licensee MDPI, Basel, Switzerland. This article is an open access article distributed under the terms and conditions of the Creative Commons Attribution (CC BY) license (https:// creativecommons.org/licenses/by/ $4.0 /)$.
Faculty of Technology, Natural Sciences and Maritime Sciences, University of South-Eastern Norway, 3184 Vestfold, Norway; kcz@usn.no

\begin{abstract}
Oil and gas offshore exploration and production (E \& P) will remain necessary to meet increasing global energy demands. However, appraising and exploring these resources has a major impact on sustainability and faces many challenges. Improving the supply chain operations that support E\&P activities presents opportunities to contribute to the United Nations (UN) Sustainable Development Goals (SDGs), but relies on organizations being able to adopt new strategies and technology and, innovate their current business models. Business model innovation (BMI) has not been actively pursued in this industry, partially due to the traditional operation management and due to the complexity in changing established models or adopting full-fledged archetypes. Thus, the present study proposes a more flexible and granular approach to BMI by defining elements to be adopted rather than proposing business models archetypes. To define the elements, an application of systems engineering (SE) is adopted through a morphological analysis (MA). They are presented in morphological boxes in three dimensions-technology, organization, and the human elementinspired by sustainable business model (SBM) literature. The elements are proposed as "bricks" for BMI where they can be adopted and re-arranged as necessary, providing granularity and flexibility to facilitate BMI for organizations of varying sizes.
\end{abstract}

Keywords: offshore exploration and production; offshore supply chain operations; business model innovation; sustainable development goals; morphological analysis; systems engineering

\section{Introduction}

The offshore exploration and production (E \& P) industry will persist as a relevant source of energy for many years as the global energy demand continues to increase [1-3] and the renewable sources of energy are not sufficient to suppress the demand within plausible cost and at large scale [3-5]. This industry contributes with resources that generate electricity, heating, and other sub-products that are used as inputs in the fabrication of plastic, rubber, solvents, and many other items [1,5,6]. Additionally, its petroleum subproducts constitute the main source of fuel for almost all transportation modes utilized in the transport of people and goods worldwide [5-7]. However, emissions from burning fossil fuels impact the environment directly, resulting in global warming and climate change [8-11]; also, minimizing the impact of industrial activity lies within the United Nations (UN) Sustainable Development Goals (SDGs), a set of interconnected directions to guide the international community towards a sustainability agenda [10].

Offshore E \& P is an industry that plans, builds, and operates offshore structures in the open sea to extract and retrieve resources through the execution of industrial activities that range from the search for oil and gas and its exploration, to transportation to shore and all steps in between [12]. Its value chain is divided into three major groups: upstream, midstream, and downstream. The upstream consists of exploration and production (E \& P) activities that involve field appraisal and development, drilling, operations, maintenance, 
and decommission activities. Oil refining is handled midstream, while wholesale, distribution, and marketing are part of the downstream. As a general rule, upstream ends at the extraction of crude oil and its transportation to another destination $[8,13]$. The present study focuses on the E \& P activities conducted offshore. These E \& P activities are supported by supply chain operations (hereby called SC) that are conducted by a vast network of suppliers, terminals, vessels, and others operating in an intricate web that involves a large amount of money, hazards, and possible environmental impact [14-16]. Figure 1 shows this relationship. Building and delivering platforms and their parts, materials, equipment, and offshore personnel are challenging tasks that depend on numerous stakeholders that are directly and/or indirectly interrelated and inter-dependent to successfully perform the tasks $[1,14,15]$.

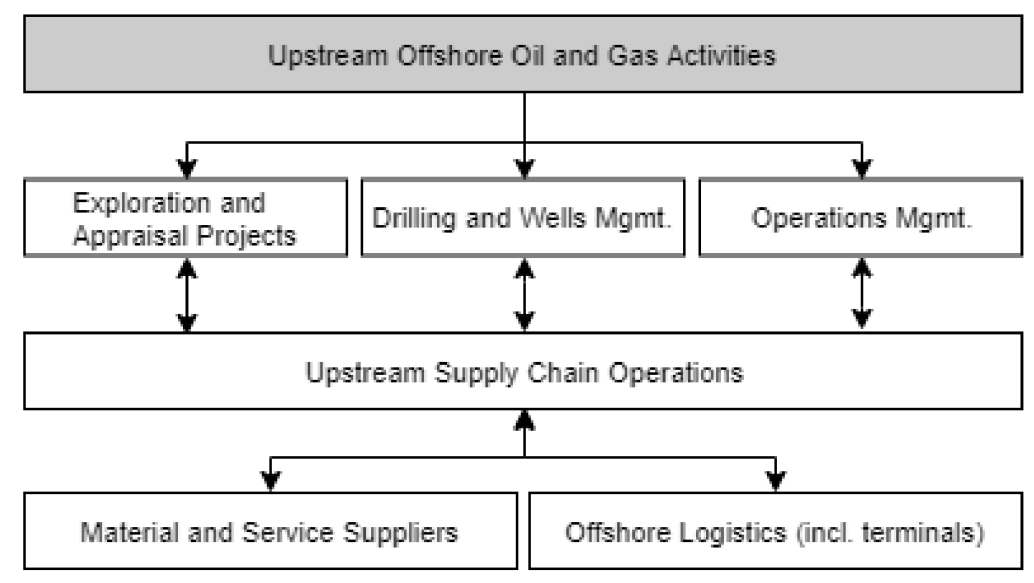

Figure 1. Offshore exploration and production (E \& P) activities and its supply chain operations support.

Offshore E \& P SC operations increased in complexity as the search for resources moved from shore and shallow waters to reach resources in deeper waters and more remote locations with extreme operating conditions $[1,8,13]$. In turn, the added complexity contributes to additional safety and environmental risks [1,17]; a higher level of environmental impact, such as carbon dioxide $\left(\mathrm{CO}_{2}\right)$ emission [1,18]; and other concerns that have subjected the industry to strict regulation. Therefore, improving these operations can help the industry achieve its SDGs, as suggested in Figure 2.

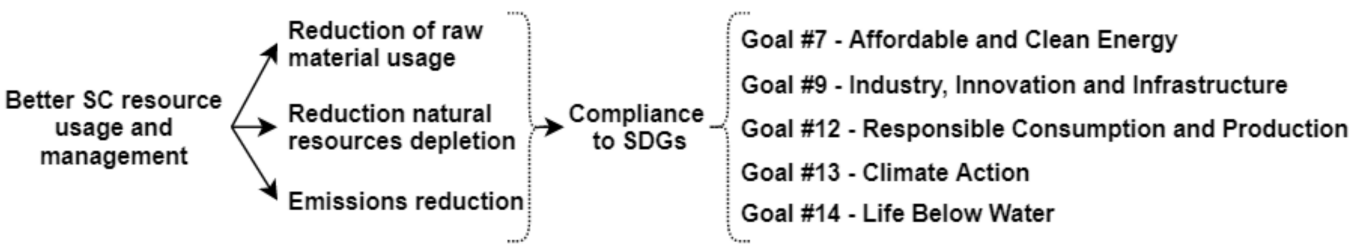

Figure 2. Supply chain management and Sustainable Development Goals (SDGs) relationships [9].

Despite many initiatives to contribute to SDGs, the industry is failing to meet its goals $[4,19]$, especially $\mathrm{CO}_{2}$ emission reduction [19]. The existing business models are recognized as the reason because traditional organizational frameworks hinder the industry from succeeding in its improvement efforts [20-22]. Instead, many have suggested that business model innovation (BMI) and the adoption of sustainable business models (SBMs) as a solution [23-25]. However, the literature available on BMI techniques seem to disagree in regard to what is the best approach [24,26,27]. In addition, changing, innovating, and adopting new business models may demand a near-complete organizational restructure $[26,28,29]$, which can be challenging for established organizations and a major 
task for smaller ones. Therefore, a more flexible and granular approach to BMI has also been recommended $[26,28]$.

The present study addresses this recommendation through the identification and proposal of design elements to be adopted in the BMI process instead of creating another business model archetype. Addressing complex structures, such as the offshore E \& P SC operations' ecosystem, can benefit from a systematic approach $[30,31]$. As the industry is already familiar with systems engineering methods, a morphological analysis [32-34] was conducted to identify and define the elements proposed in this study, and Tukker's [35] product-service system framework is applied to identify the classic and the new business models in the industry. The present study's assumption is that, by adopting the identified elements at different levels in the organization, they work to improve the offshore E \& $\mathrm{P}$ SC operations and thus contribute to the SDGs. The identified elements are examined in morphological boxes, as presented by Kley, Lerch, and Dallinger [36], and are presented in three main dimensions-technology, organization, and the human element-inspired by the SBM archetypes proposed by Bocken, Short, Rana, and Evans [37]. Figure 3 shows the conceptual framework adopted in this study.

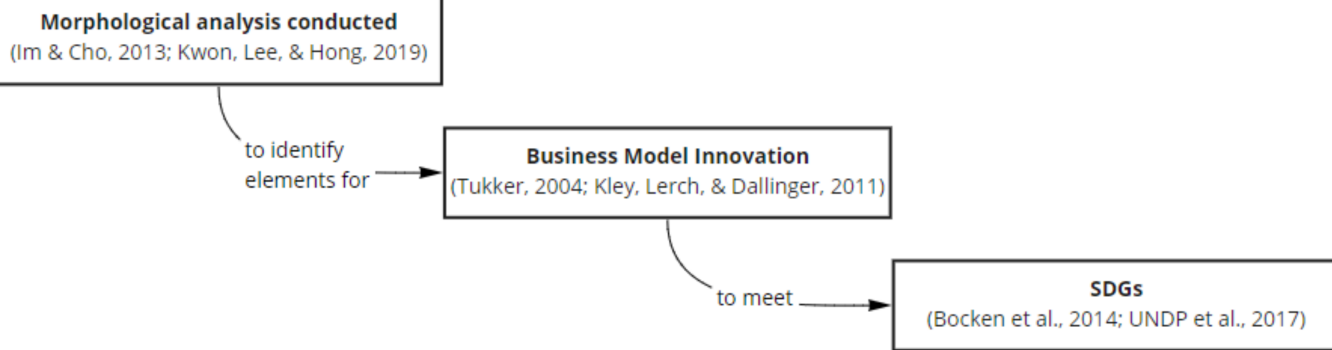

Figure 3. Conceptual framework and study contribution: relationship between morphological analysis (MA) and SDGs.

The study then continues as follows. This section continues to present a literature review on business models and BMI in the context of offshore E \& P and its supply chain operations. Section 2 presents the morphological analysis conducted; Section 3 presents the identified elements to be adopted for BMI in morphological boxes and discusses their characteristics. Section 4 discusses how the proposed elements related to "new business models" typology can address SDGs and value proposition, creation, and capture in the context of offshore E \& P industry. Finally, Section 5 presents conclusions and future research directions.

Business models and business model innovation. Existing business models have been widely discussed, particularly addressing value realization from technology innovation [20, 38,39]. Even though many definitions exist in terms of what a business model is [27], the present study adopts the concept that a business model is a structural tool for companies to operate, manage, assess performance, and innovate their business [37,40,41]. Focusing on technology, Chesbrough [42] argued that there are four functions of a business model: (1) to articulate the value proposition for users, (2) detect a market segment where the technology has a purpose, (3) state the value chain involved in realizing the offering, and (4) evaluate the cost structure and profit potential from the offering(s). Trott [43] complements these definitions by saying that a business model is the framework for an organization to realize profit through the successful creation, marketing, and value delivery to its customer. As such, the business model framework consists of three elements: (1) value proposition, (2) value creation and delivery, and (3) value capture [37,41]. Value proposition concerns the product and/or service offered in order to generate financial return, and which consumer segments are in focus [37,44]. Value creation and delivery concerns the resources utilized to deliver the value proposition, including the performed activities, partners, distribution methods, and technology [37,41]. Finally, value capture concerns how revenue is captured, including cost reductions $[37,40,41]$. 
According to Chesbrough [42], beyond describing how an organization works and generates value, these elements present opportunities to capture value from innovation. Zott et al. [27] affirmed that business models are vehicles for innovation in organizations and subjected to innovation themselves to fulfill that role. Consequently, a business model is not a static framework that an organization must follow, but a transient, dynamic system that must change and adapt so that the organization remains viable and successful in the long term [28,45]. This continuous change process is referred to as business model innovation [28]. Innovating business models go beyond the creation of new products and services. It requires managers to break their cognitive barriers towards going beyond their own or their organization's culture of conservatism and passiveness towards adopting new elements $[39,46]$. Business model innovation depends on the evaluation of how the business model's components work towards the organization's desired outcome, and a few tools are available to assist this process, such as the business model canvas by Osterwalder and Pigneur [41], the St. Gallen business model navigator [39], and the triple-layered business model canvas [47], which focuses on designing sustainable business models.

The offshore E \& P industry has a traditional approach to business models, and disruption of these models requires penetration of a high barrier imposed by conservatism and vested interest [48-50]. Yet, technological advances and regulations are having an effect in fostering the disruption of the traditional business models either by necessity or competitive advantage [50-52]. Many changes in the oil and gas industry occur in response to specific situations, such as low oil prices, and external pressure such as legislation and other regulations $[48,50,53]$. Thus, in times where challenges are constantly threatening "business as usual", innovation provides opportunities and casts light on possibilities for the industry. Early initiatives proved the possibility of success in changing business models through innovation, such as through coopetition and the creation of joint ventures and alliances [54-56]. A good example comes from the oil and gas industry in Norway, where an alliance allowed Aker BP's, a Norwegian operator, to deliver the Valhall Flank West exploration platform in 14 months and under budget, from the first steel to first oil [57]. This approach to the sharing economy proves that re-thinking how to conduct operations together with suppliers and even competitors can have a long-term positive impact on securing cash flow and stability in low markets, even if profits may be slightly lower. It translates the idea of selling/buying a specific service, rather than managing the whole supply chain. Such innovative initiatives affect business models as they disrupt many parts of the industry. Other innovations include the use of drones for delivery and inspection, robots for performing risky tasks, automation for operational efficiency, 3D printing, etc. $[21,22,53]$. While not all of these initiatives are fully mature, they show that stakeholders can become cooperative partners with a higher degree of resource sharing to create a service-oriented culture and a communal approach to offshore E \& P SC operations. They are also good examples of why and how re-evaluating existing business models is necessary.

\section{Materials and Methods}

The purpose of this study is to define elements that can be adopted for BMI in the offshore E \& P SC, identified through a morphological analysis (MA) [32-34,58]. According to Martin [58], a morphological analysis is conducted to perform a systematic classification and assessment of possible combinations of alternatives that can, together, provide a certain function. To identify the elements to be included in the analysis, business models, BMI, SBMs, offshore E \& P, and E \& P SC literature was examined (collected from databases such as Scopus and Web of Science, among others); and information available from oil and gas related organizations (such as IPIECA and DNV-GL, among others) was collected through publications and reports made available by these organizations.

In the sequence, the identified elements were classified through the application of Tukker's [35] business model typology, which lead to the identification of the elements that belong to classic business models and those that belong to new business models. 
Tukker [35] classified a business model by the way it generates value, placing it within a range that starts at value generation mainly from products (tangible) towards value generation from services (intangible). At an operational level, the value generation process moves from being product-oriented towards being use-oriented and result-oriented [35]. Applying this framework (Figure 4) to the offshore E \& P industry supply chain results in three main categories: (1) the operator owns and/or manages all parts of its supply chain; (2) the supply chain operations are purchased/offered as a service (defined by its use), and (3) the operations have a communal approach, where assets and others are shared within the supply chain, towards the outcome of the service. The first category represents the classic business models in the industry, whereas the other two range towards new business models.

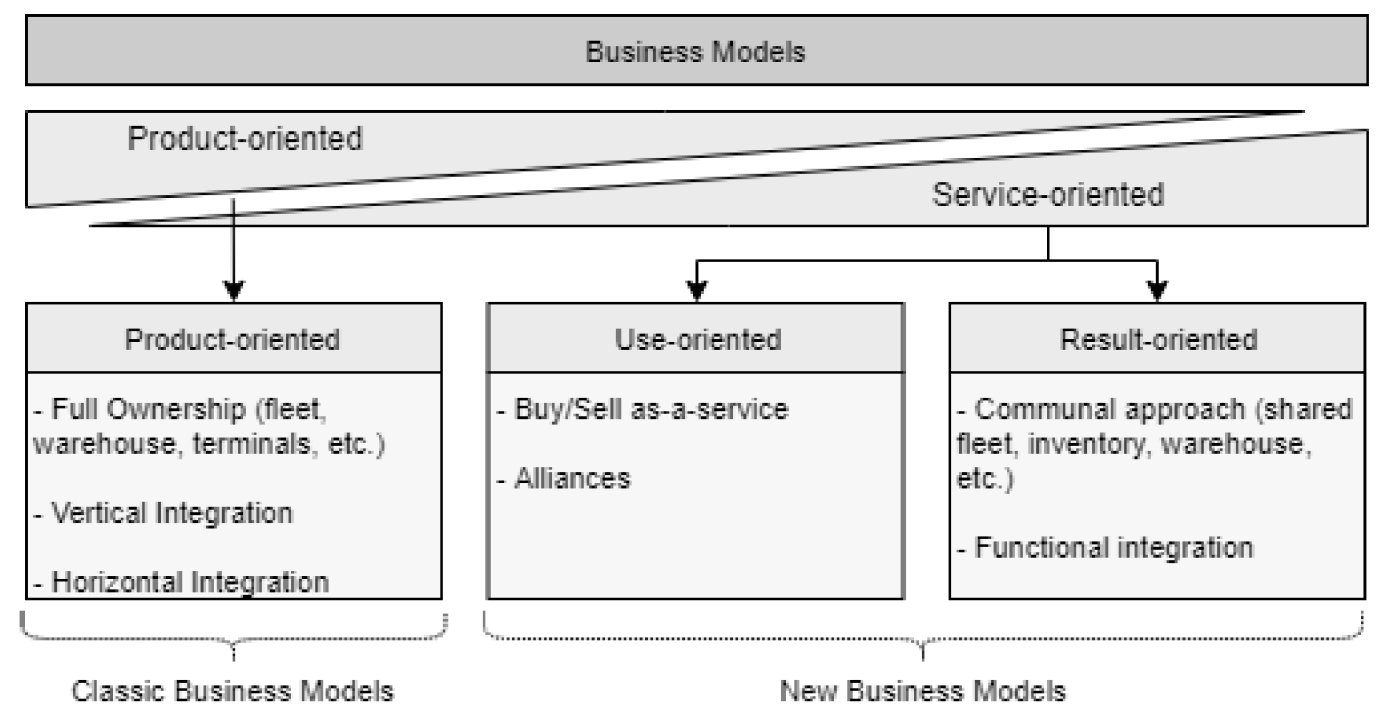

Figure 4. Tukker's [35] typology applied to the offshore E \& P supply chain (SC).

To present the elements and their characteristics, the concept of morphological boxes is applied, adapted from Kley et al. [36]. Subsequent to a morphological analysis, morphological boxes "represent a creative way to illustrate all the potential solutions to existing problems in a structured format by defining different features with several configurations with regard to a problem" [36] (p. 3395). Figures 5-7 present three morphological boxes with the identified design elements for business model innovation. Addressing sustainability, these elements are presented based on a list of characteristics related to the three dimensions adapted from Bocken, Short, Rana, and Evans [37]; that is, technology (Figure 5), organization (Figure 6), and the human element (Figure 7). Each box follows a logic in its presentation regarding the infrastructure and organizational changes needed for adoption - the elements more to the left are less complex and require the adoption of less extensive changes. On the other hand, the elements more to the right are more complex and thus require more changes. The proposed elements placed most to the right of the morphological boxes are suggested as an ultimate goal for organizations to adopt, although their complexity means it might not be possible for organizations to adopt them at first. For this reason, the other elements situated to their left in the boxes are proposed to be adopted as interim stages during business model innovation. After presenting the elements to each factor, I discuss how the elements classified in the new business models typology address sustainability and their value proposition, creation, and capture.

\section{Results}

\subsection{Technology-Related Elements: Characteristics and Contributions to SDGs}

The morphological box in Figure 5 presents elements and their characteristics related to technological development and deals with different aspects of technology use and 
application in the offshore E \& P industry. From left to right, the presented elements increase system interoperability, proposing a higher level of automation as a value for a business model if the alternative is to be adopted.

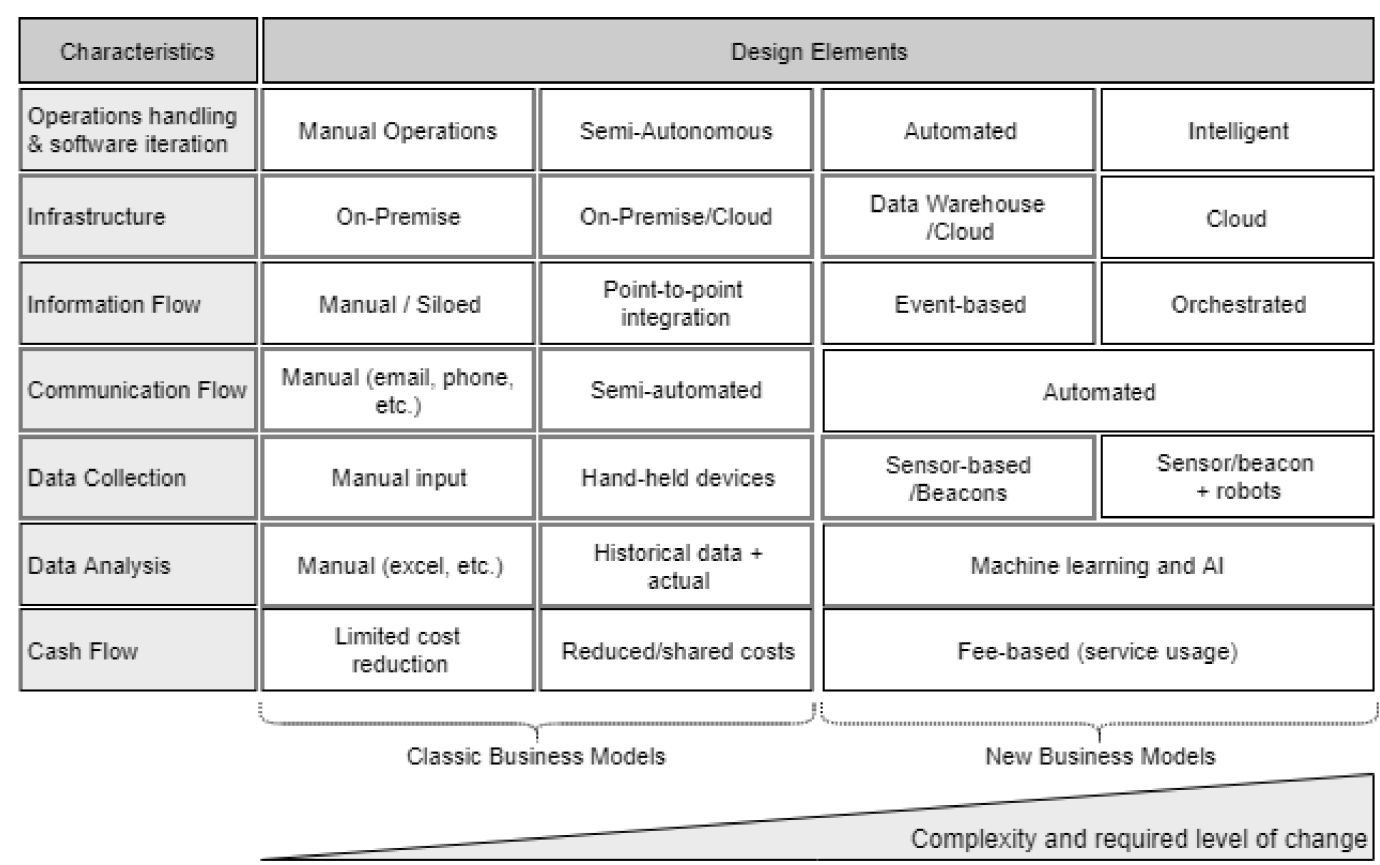

Figure 5. Morphological box for technology-related elements of business models (adapted from [36]).

The first row of design elements depicts technology applications to conduct basic operations and the reliance on manual interaction with systems and software. It ranges from operations being conducted manually, where human resources are needed to input, verify, and exchange information and data throughout the software portfolio in order for operations to be fulfilled. On the other extreme of the array, the presented element is understood as an intelligent element, where the data collected from operations using digital technologies are utilized as input for the system to conduct its own operations, based on algorithms and possibly machine learning and artificial intelligence. Manual interaction can still occur, but it is shifted from data input towards data usage for the supervision of operations, higher-level decision-making and operations' reporting indicators. The next characteristic, infrastructure, evolves from left to right to support the level of automation proposed in line with other elements. The same logic applies to the other characteristics and their elements.

The last element, cash flow, proposes how operational cost is reduced by each element as they help diminish the manual interference to daily activities, manual errors, and other potential issues caused by the lack of integration between activity, process, and software. Its first element relates to the possible level of cost cutting when operations are conducted mostly manually, and technology infrastructure and administration is mostly managed in-house. Once the elements evolve towards interoperability and automation, the cost reduction possibilities increase, as operations are not reliant on manual interactions and cost migrates to payment per service usage. The elements presented for each characteristic introduce stability, efficiency, and resistance to human error due to the increased automation levels they proportionate.

\subsection{Organization-Related Elements: Characteristics and Contributions to SDGs}

Similar to Figure 5, the presented design options for the organizational characteristics (Figure 6) evolve from left to right with higher levels of interrelationship. In this dimension, the further to the left the element is, the more internal it is to the organization and silo 
based. The further to the right, the higher the level of partnership and collaboration with stakeholders is necessary and achieved. The presented organizational elements offer value to the business model by providing the opportunity for organizations to change processes that are inefficient and outsource activities that are not core to the organization. This also creates value to the other stakeholders in the value chain, as each stakeholder can become more specialized in its functional area, to innovate and reduce cost by eliminating non-core related activities.

\begin{tabular}{|c|c|c|c|c|}
\hline Characteristics & \multicolumn{4}{|c|}{ Design Elements } \\
\hline Structure & $\begin{array}{l}\text { Closed/vertically } \\
\text { integrated }\end{array}$ & $\begin{array}{l}\text { Horizontally } \\
\text { Integrated }\end{array}$ & Alliances & Communal \\
\hline Planning Horizon & Short-term & Mid-term & Long-Term & Very Long-term \\
\hline $\begin{array}{l}\text { Operational Planning } \\
\text { Strategy }\end{array}$ & Reactive & Proactive & \multicolumn{2}{|c|}{ Strategic } \\
\hline Soucing Strategy & $\begin{array}{l}\text { High number of } \\
\text { suppliers }\end{array}$ & $\begin{array}{l}\text { Few strategic } \\
\text { suppliers }\end{array}$ & \multicolumn{2}{|c|}{ Pre-certified suppliers + market bidding } \\
\hline $\begin{array}{l}\text { Procuring Invoicing } \\
\text { /payment strategy }\end{array}$ & $\begin{array}{l}\text { Manual Purchase order } \\
\text { and invoicing }\end{array}$ & $\begin{array}{c}\text { Semi-automated } \\
\text { Purchase order and } \\
\text { invoicing }\end{array}$ & \multicolumn{2}{|c|}{$\begin{array}{l}\text { Contract/activity triggered - auto Purchase Order } \\
\text { and invoicing }\end{array}$} \\
\hline Inventory strategy & Owned & Owned + rented & $\begin{array}{l}\text { VMI (Vendor Managed } \\
\text { Inventory) }\end{array}$ & $\begin{array}{l}\text { Strategic items/parts } \\
\text { at the supplier }\end{array}$ \\
\hline $\begin{array}{l}\text { Warehouse / terminal } \\
\text { strategy }\end{array}$ & Owned & Leased/rented & \multicolumn{2}{|c|}{ At the supplier } \\
\hline Contract Strategy & Long-term & Spot & Frame-agreement & $\begin{array}{l}\text { Strategic / Incentive- } \\
\left.\text { based (ex. MLC }{ }^{1}\right)\end{array}$ \\
\hline $\begin{array}{l}\text { Transport Sourcing } \\
\text { Strategy }\end{array}$ & Owned & Long-term rental (FFA) & $\begin{array}{l}\text { Spot market and/or } \\
\text { Pool }\end{array}$ & $\begin{array}{l}\text { Fully shared } \\
\text { (freight-based) }\end{array}$ \\
\hline Transport Operations & Manual set-up & $\begin{array}{l}\text { Pre-established } \\
\text { routes/date plan }\end{array}$ & \multicolumn{2}{|c|}{$\begin{array}{l}\text { Activity and cargo } \\
\text { based through Algorithm determination }\end{array}$} \\
\hline Transport Strategy & Exclusive vessel & $\begin{array}{l}\text { Shared vessel } \\
\text { (intra-company) }\end{array}$ & $\begin{array}{l}\text { Shared vessel (agreed } \\
\text { multi-company) }\end{array}$ & $\begin{array}{l}\text { Freight/deck space } \\
\text { based (ex. log. hub) }\end{array}$ \\
\hline Cash Flow & Limited cost reduction & Reduced/shared costs & \multicolumn{2}{|c|}{ Fee-based (service usage) } \\
\hline & \multicolumn{2}{|c|}{ Classic Business Models } & \multicolumn{2}{|c|}{ New Business Models } \\
\hline
\end{tabular}

Figure 6. Morphological box for organization-related elements of business models (adapted from [36]).

The first characteristic in Figure 6 specifies the organizational structure of the offshore E \& P SC, ranging from closer operations handling within the operator (owned vessels, warehouses, etc.) towards partnerships, alliances (strategic suppliers are preferred) and sharing assets and other resources. For example, if the structure consists of alliances involving strategic suppliers, the sourcing strategy will consist of selecting these suppliers that already have certifications and contracts relevant to the operations to be conducted. This logic also applies to the invoicing and payment strategy to be adopted, as well as to the inventory, warehouse/terminal, contract, and transport sourcing ones. Accordingly, the operational planning strategy is replicated through the organizational structure adopted. Following the same example, if the suppliers involved are pre-selected and certified through supply chain processes by the business units responsible for that process, a longer activity span can be planned towards that partnership/alliance, which provides a longer-term planning range. This directly impacts operations, as a longer planning range produces visibility and better resource allocation. Transport, operations, and sourcing strategies are also interrelated and highly dependent on the structure adopted. Continuing to follow 
the above example, a fewer number of selected suppliers participate in the majority of operations, which makes it possible to share a higher level of information and data within the network that can be used for operations optimization and cargo allocation, reducing the manual input to handle operations. Therefore, data from operations becomes the trigger and input towards reserving space and capacity for sourcing transport (that is, transporting something from A to B for a fee) and handling transportation resource sourcing (that is, the number of vessels needed to deliver items related to an activity). The way in which these elements are combined and selected directly impacts the value capture element proposed-cash flow. If the operational elements adopted relate to a closed structure, the cost reduction opportunities are limited as there is lower flexibility in terms of pooling suppliers and negotiation. On the other side of the array, costs are related to the used services, depending on operational optimization and resource usage.

\subsection{Human Element-Related Elements: Characteristics and Contributions to SDGs}

In the offshore E \& P SC context, the human element is two-fold, consisting of (1) the people working on the offshore platforms, drilling rigs and FPSOs (floating production storage and offloading), and (2) the people working onshore planning and executing commands towards the operations execution. Hence, both aspects need to be considered when evaluating the impact on the human element and its place in the organizational structure and business model. The morphological box in Figure 7 presents business model elements related to the management of the human element.

\begin{tabular}{|c|c|c|c|c|}
\hline Characteristics & \multicolumn{4}{|c|}{ Design Elements } \\
\hline Operation Handling & Full Interaction & High interaction & Low interation & No interaction \\
\hline Work Organization & Business Unit-centric & Asset/Platform centric & Alliance centric & Per contract \\
\hline Work Specialization & $\begin{array}{c}\text { Low (manual input / } \\
\text { workers) }\end{array}$ & $\begin{array}{l}\text { Medium (technicians, } \\
\text { business analysts) }\end{array}$ & $\begin{array}{l}\text { High (divers, offshore } \\
\text { drilling superintendent) }\end{array}$ & $\begin{array}{l}\text { Very High (drilling } \\
\text { engineers) }\end{array}$ \\
\hline Work Schedule & Fixed hours & Fixed rotation & Flexible/ad-hoc & $\begin{array}{l}\text { Activity and/or } \\
\text { contract based }\end{array}$ \\
\hline Work Location & Onshore office & Offshore & $\begin{array}{l}\text { Onshore Control } \\
\text { centers/terminals }\end{array}$ & Flexible \\
\hline \multirow[t]{2}{*}{$\begin{array}{l}\text { Contract/ Payment } \\
\text { strategy (Cash Flow) }\end{array}$} & Fixed contract & $\begin{array}{c}\text { Temporary contract } \\
\text { (short } \\
\text { and mid-term) }\end{array}$ & $\begin{array}{l}\text { Flexible/ad-hoc } \\
\text { (hourly rates) }\end{array}$ & $\begin{array}{l}\text { Activity based (agreed } \\
\text { price for an activity) }\end{array}$ \\
\hline & \multicolumn{2}{|c|}{ Classic Business Models } & \multicolumn{2}{|c|}{ New Business Models } \\
\hline & & & Complexity and & equired level of change \\
\hline
\end{tabular}

Figure 7. Morphological box for human-related elements of business models (adapted from [36]).

The proposed human-related elements related to operations handling, work organization, specialization, and schedule can nearly or completely eliminate the human involvement in supply chain operations. However, this is not necessarily the intention. The idea is that these elements change how and where humans interact and fulfill activities in the organizations. Hence, when related to humans directly, the presented elements show increased specialization and reduced commitment to one specific contract/organization from left to right in Figure 7. This creates value to organizations by being able to work with highly skilled professionals without worrying about talent retention. However, this does not mean that the link to the organization should be weaker; it simply provides the organization and the professionals with the opportunity to work with multiple parties if they want, and gives flexibility to the professionals to elect the best possible places to work, addressed by the work schedule and location elements. This allows organizations to 
reduce personnel costs as they will not have to maintain several idle people that do not have constant activity in the company simply to avoid missing the skilled professional to another organization, addressed by the contract/payment strategy element.

\section{Discussion}

There are many ways in which the offshore E \& P industry can contribute to the SDGs [9], although most efforts are directed to minimizing the impact of drilling and platform operations $[1,9,19]$, such as water and waste management $[1,59]$, and managing $\mathrm{CO}_{2}$ emissions $[1,3,60]$. However, many opportunities exist in the management of the supply chain operations conducted to support the upstream activities.

In the offshore E \& P industry, the supply chain is a complex "ecosystem" that includes many internal and external stakeholders that must comply with many different legislations and overcome many challenges. The SC operations are conducted by specialized suppliers, supply bases, terminals and warehouses (referred to hereafter as support companies) that provide vessels, transportation and storage, manning, and other services, usually managed by the operator hiring them $[14,61,62]$. The vessels involved in the offshore E \& P SC to complete these activities are major contributors to $\mathrm{CO}_{2}$ emissions in the offshore E \& P industry [1] and most sustainable initiatives in this context are linked to the reduction of $\mathrm{CO}_{2}$ emission from the vessels utilized in transportation, optimal vessel and route allocation, vessel fuel usage, and route optimization for transportation [14,63,64]. Lately, the adoption of technology for this purpose has been widely discussed, such as the implementation of 3D printing of spare parts for local supply to avoid transportation; and the adoption of Blockchain, Internet of Things (IoT), and digital twins for supply chain transparency $[19,65,66]$. For vessel and deck space optimization, the adoption of big data analytics and machine learning/artificial intelligence has been widely discussed [67-69].

However, there are many other ways in which supply chain operations can improve to contribute to SDGs, such as a more efficient management of inventory to increase inventory usage and reduce new parts purchasing, reducing double-purchases, fostering inventory sharing throughout the supply network, and other initiatives that could be adopted to reduce the production of new items that rely on global natural resources $[4,70,71]$. A more collaborative approach to supply chain handling can also provide results; instead of each operator managing their own vessels, these can be pooled to promote sharing vessel deck transportation capacity, leading to a better vessel capacity allocation and an overall reduction in the number of vessels and vessel voyages required to transport cargo $[4,70,72]$. Table 1 summarizes potential areas of change that would effectively contribute to meeting SDGs.

Table 1. Summary of potential contribution to SDGs.

\begin{tabular}{cc}
\hline SDG Number & Main Potential Contribution \\
\hline SDG 14 & $\begin{array}{c}\text { Minimize the impact of drilling and platform operations; } \\
\text { water and waste management in platforms and vessels } \\
\text { Managing } \mathrm{CO}_{2} \text { emission }\end{array}$ \\
SDG 12 & $\begin{array}{r}\text { More efficient management of inventory leads to better purchasing } \\
\text { behavior and less consumption }\end{array}$ \\
SDG 9 & $\begin{array}{c}\text { Inventory sharing throughout the supply network reduces the } \\
\text { production of new items that rely on global natural resources } \\
\text { Less stranded inventory leads to less scrapping, leading to higher } \\
\text { savings and potentially reducing the final cost of energy provided. }\end{array}$ \\
\hline
\end{tabular}

Therefore, a more flexible and granular approach to setting and meeting goals toward SDGs is suggested for designing business models that can support innovation, technology adoption, and other changes without having to restructure the whole business model and/or organization. The objective of the present study is to present elements that can be more easily adopted and replaced as wished by organizations to create new business 
models. Systems engineering methods are ideal to support this objective as they promote a systematic approach to solving an array of complex issues in systems present in several domains. The SE method adopted in this study-morphological analysis-provides this systematic approach and supports non-quantified modeling that allows an in-depth analytical exploration to solve a complex issue $[30,31,73]$. Specifically, the present study used SE methods to identify and propose design elements for BMI. The resulting elements presented function as "construction bricks" that, once combined, allow the creation/innovation of a business model that fits the organizations' objectives and addresses sustainability at the same time at different intra- and inter-organizational levels. This flexibility enables organizations of different types and sizes to implement design elements that address sustainability without having to replace their entire existing business model or implement traditional sustainable business model archetypes. Therefore, if one desired element cannot be implemented initially, another one can be utilized instead as an interim state, while the desired element works as a final goal. Beyond sustainability, the elements are proposed to foster technology adoption where it is needed, organizational innovation and collaboration as value creation. These elements are presented according to Tukker's [35] typology, categorized as "classic business models" and "new business models". The elements included in the latter are suggested for the offshore E \& P industry to adopt to manage its supply chain operations. Once combined, these elements address SDGs in different ways, and their recombination by the organizations can be re-adjusted to meet organization's strategies and purpose. How these elements address business models' value proposition, creation, and capture and contribute to the SDGs is summarized in Figure 7 and discussed in the sequence.

\subsection{Value Proposition}

The elements value proposition is to offer the integration of offshore E \& P SC operations through suitable technology to allow the stakeholders to reach a communal approach to operations handling. By integrating operations, operators and other stakeholders can make better usage of their own operational data, which provides insight regarding the items to be purchased and transported and the services needed. Consolidating this demand through data collection and predictive analysis provides opportunities for the support companies to adjust their fleet according to the demand and forecast with a higher accuracy, which, in turn, allows the support companies to adjust the level of service to the capacity needed. Thus, vessels and other resources can be pooled and shared instead of each operator renting its own. The proposed elements also address the interconnection among vessels, ports/terminals, platforms, other stakeholders and the human element in the industry. This is essential to prepare the industry for implementing innovation and other technological developments such as autonomous vessels, cranes, ports, etc. These are in constant evolution but cannot be adopted if the industry is not ready to adapt. The autonomous assets must be able to intercommunicate to work beyond their technical aspects-an autonomous vessel still needs to dock, just like an autonomous crane still needs to know what it will lift, from where, and where to place the cargo. However, manual interference is not the solution, as machines must be interoperable through machine understandable languages. Hence, the automated and "intelligent" elements in this category define the solutions offered and the stakeholders involved towards operations' completion.

\subsection{Value Creation}

The elements create value creation through the adoption of automation and intelligent elements to promote a more efficient handling of the supply chain operations and to allow supply chain partners to offer a better service to its customers. Re-thinking how the stakeholders collaborate, communicate, and work is a necessity not only for the stakeholders themselves, but also for the industry to incorporate and benefit from the innovations brought from technological advances being presented to address efficiency, safety and environmental concerns. Even though the elements emphasize integration and automation, 
people are not eliminated from the system. People have unique characteristics, such as creativity, negotiation, and problem-solving, that extend beyond what was coded into a software for conducting operational tasks. However, people are being used as a cog in the system, whereas they should be placed where interpersonal skills are needed the most, leaving the machines to do what they do best and enabling people to do what they do best: create, develop, and innovate. Hence, technology is part of this change, and technological efforts to digitalize the synergies among the network participants are needed for them to work together. Similarly, it is just as necessary for the offshore E \& P domains to extend their willingness for technology to go beyond machines and engineering to reach supply chain operations, so that innovative ways of working can be developed and implemented, thus creating value throughout the organization's value chain.

\subsection{Value Capture}

The elements capture value by reducing costs and waste through better utilization of resources, such as fleet, vessels, inventory, personnel, etc. This promotes operational efficiency and reduces operational costs, increasing revenue and additional profit opportunities for organizations. Using inventory as an example: better inventory visibility enables a more efficient management of inventory and purchasing, which enables the use of the available items instead of unnecessary double-spending for "emergency" purposes, thus reducing the overall quantity of general and unused inventory. With less stranded inventory, less scrapping is executed, and more money and taxes are saved and made available to be used elsewhere, potentially reducing the final cost of energy provided.

\subsection{SDGs}

The "new business models'" elements address SDGs by changing how work is conducted, as summarized in Figure 8. This shift from manual work to automation reduces human interactions in operations, resulting in fewer error opportunities that could lead to accidents, thus enhancing safety in offshore logistics operations. Together with automation, increased collaboration allows streamlining planning and provides operational synchrony. This results in better use of resources such as vessels, leading to a higher level of vessel deck capacity usage and a reduced number of voyages from and to the offshore platforms, contributing to safety and addressing environmental concerns due to reduced chances of spillage and reductions of $\mathrm{CO}_{2}$ levels, in line with the UN's SDGs. Finally, better purchasing and inventory handling reduces the number of items that need to be purchased, which reduces the need for transportation and fabrication. With fewer items to produce, less raw material is needed, reducing the depletion of natural resources.

\begin{tabular}{|c|c|c|c|}
\hline Value Proposition & Value Creation and Delivery & Value Capture & SDGs \\
\hline $\begin{array}{l}\text { An automation-based, data- } \\
\text { based and integrated } \\
\text { approach to conducting } \\
\text { supply chain operations to } \\
\text { upstream oil and gas, deriving } \\
\text { a communal approach to } \\
\text { asset usage and capacity } \\
\text { handling. }\end{array}$ & $\begin{array}{l}\text { Through a communal } \\
\text { approach, sharing resources } \\
\text { leads to a more efficient } \\
\text { resource allocation, } \\
\text { decreasing the number of } \\
\text { resources needed and their } \\
\text { usage to conduct operations. }\end{array}$ & $\begin{array}{l}\text { Cost reduction through better } \\
\text { utilization of resources; } \\
\text { Increased profit/revenue } \\
\text { opportunities from selling } \\
\text { stranded capacity (e.g. extra } \\
\text { space in vessels) }\end{array}$ & $\begin{array}{c}\text { Focus on SDGs \#13 } \\
\text { (Take urgent action to combat } \\
\text { climate change and its } \\
\text { impacts) } \\
\text { and \#14 } \\
\text { (Conserve and sustainably } \\
\text { use the oceans, seas } \\
\text { and marine resources for } \\
\text { sustainable development) }\end{array}$ \\
\hline
\end{tabular}

Figure 8. Value proposition, creation, capture and contribution to SDGs from the elements proposed in the "new business models" category (adapted from [37]).

\section{Conclusions}

Potential new and adaptive business models that can lead to the success of innovations and their diffusion are yet to be widely explored. In the meantime, new products, services, and technology are constantly being released to the market. This gap between technological advances and organizational needs must be addressed if the industry is to succeed in a 
demanding future, where regulation is increasingly challenging due to environmental worries, technology develops faster than ever, and a globalized world created a complex industry that requires pioneering alternatives to overcome constraints and competition. The offshore E \& P industry must research, develop, and adopt not only technical innovation, but also have a holistic approach to business model innovation that will help understand which innovation and technological initiatives will promote sustainability and value creation in the organizations and their industry context. The existing business models that are available no longer meet the industry's needs to overcome its challenges and address sustainability and SDGs. However, finding and adopting business model archetypes that can handle such complexity and allow adopting innovative solutions might not be possible. At the same time, the existing archetypes might be too complex or robust for organizations to adopt as they imply changes necessary throughout the whole organization.

This conceptual study has applied systems engineering methods to explore the business model innovation possibilities in the offshore $\mathrm{E} \& \mathrm{P}$ industry and its support ecosystem. It offers a more flexible and granular approach to business model innovation through the adoption of SE to propose elements to be adopted interchangeably that can be adopted at different organizational levels and timeframes and can function as interim or final stages for the organization. Through examining business models typology and the conduction of a morphological analysis, possible elements for business models' innovation are identified according to classic and new business model typology and presented against three dimensions: technology, organization and the human element. The elements are presented in morphological boxes and can be combined and reorganized to change and build different business models. Given the limitations that more established firms may face in adopting certain elements, this study proposes elements as pieces for the organizations to adopt instead of full-fledged archetypes, providing modularity and granularity to organizations to replace certain parts when necessary without having to change the whole business model many times. The presented elements show different levels of complexity and organizational change for their adoption, and the more complex ones are suggested as an ultimate goal for adoption in business model innovation.

By adopting the elements in the new business model category, the expected end-state for the offshore E \& P SC is an ecosystem that includes stakeholders in the network as collaborative partners to deliver higher operational standards. These include taking responsibility not only for operational execution, but also over safety and the environment, thus addressing sustainability and SDGs in offshore E \& P operations. How these elements propose, create, and capture value has also been discussed. These elements create value through giving organizations an opportunity to become more strategic as they shift the daily activities from manually conducted to automated, conferring stability and reliability to activity execution and, therefore, generating value from technology application and organizational restructuring. Through more efficient information sharing, information propagates to stakeholders in the value chain more quickly, which can change how the stakeholders conduct their activities as well, taking the opportunity to remove inefficiencies from their part of the operations. Finally, as the different design elements are adopted by offshore E \& P companies through business model innovation, a new method of collaboration within the industry can surge and evolve the industry to an ecosystem that addresses sustainability, innovation, the organization, technology application, and focus on their consequences to the human element. The measurement of the extent to which these presented elements address sustainability is a limitation of this study and is suggested as future research.

Funding: This research was funded by the industrial PhD funding by the Norwegian Research Council and Aker BP, grant number 291198 and open access funding was financed by the University of South-Eastern Norway.

Institutional Review Board Statement: Not applicable.

Informed Consent Statement: Not applicable. 


\section{Data Availability Statement: Not applicable.}

Acknowledgments: The author is grateful to Associate Ziaul Haque Munim and Cecilia Haskins for feedback on earlier drafts of the manuscript.

Conflicts of Interest: The author declares no conflict of interest. The funders had no role in the design of the study; in the collection, analyses, or interpretation of data; in the writing of the manuscript, or in the decision to publish the results.

\section{References}

1. Cassagne, T.; International Petroleum Industry Environmental Conservation Association; International Association of Oil \& Gas Producers. Environmental Management in the Upstream Oil and Gas Industry; IOGP: London, UK, 2020.

2. Alvik, S.; Bakken, B.E.; Onur, O.; Horschig, H.; Koefoed, A.L.; McConnel, E.; Rinaldo, M.; Shafiei, E.; Zwarts, R.J. Energy Transition Outlook 2020-A Global and Regional Forecast to 2050; DNV GL: Hovik, Norway, 2020.

3. International Energy Agency. The Oil and Gas Industry in Energy Transitions: Insights from IEA Analysis; IEA: Amsterdam, The Netherlands, 2020.

4. Alvik, S.; Bakken, B.E.; Onur, O.; Horschig, H.; Koefoed, A.L.; McConnel, E.; Rinaldo, M.; Shafiei, E.; Zwarts, R.J. Energy Transition Outlook 2020_Power Supply and Use; DNV GL: Hovik, Norway, 2020.

5. Rodrigue, J.-P. The Geography of Transport Systems, 5th ed.; Routledge: New York, NY, USA, 2020.

6. Demirbas, A.; Bafail, A.; Nizami, A.-S. Heavy oil upgrading: Unlocking the future fuel supply. Pet. Sci. Technol. 2016, 34, 303-308. [CrossRef]

7. U.S Energy Information Administration. Energy Use for Transportation. Use of Energy Explained. 2020. Available online: https://www.eia.gov/energyexplained/use-of-energy/transportation.php\#: \{\}:text=Petroleumisthemainsource, innaturalgaspipelinecompressors (accessed on 19 November 2020).

8. Oil Industry International Exploration and Production Forum; United Nations Environment Programme Industry and Environment Centre. Environmental Management in Oil and Gas Exploration and Production: An Overview of Issues and Management Approaches; UNEP: Oxford, UK, 1997.

9. United Nations Development Programme; International Finance Corporation; International Petroleum Industry Environmental Conservation Association; Center on Sustainable Investment. Mapping the Oil and Gas Industry to the Sustainable Development Goals: An Atlas. United Nations. 2017. Available online: http://www.ipieca.org/resources/awareness-briefing/mapping-theoil-and-gas-industry-to-the-sustainable-development-goals-an-atlas / (accessed on 19 November 2020).

10. United Nations. United Nations Sustainable Development Goals-Climate Change. UN Knowledge Platform. 2015. Available online: https:/ / sustainabledevelopment.un.org/post2015/transformingourworld/publication (accessed on 19 November 2020).

11. Zalasiewicz, J.; Williams, M.; Steffen, W.; Crutzen, P. The new world of the anthropocene. Environ. Sci. Technol. 2010, 44, 2228-2231. [CrossRef] [PubMed]

12. Van Dokkum, K. Ship Knowledge—A Modern Encylopedia; Dokmar: Enkhuzien, The Netherlands, 2003.

13. Inkpen, A.; Moffett, M.H. The Global Oil \& Gas Industry: Management, Strategy E Finance; PennWell Books: St. Tusla, OK, USA, 2011.

14. Aas, B.; Halskau, Ø., Sr.; Wallace, S.W. The role of supply vessels in offshore logistics. Marit. Econ. Logist. 2009, 11, 302-325. [CrossRef]

15. Olesen, T.R. Offshore Supply Industry Dynamics: Business Strategies in the Offshore Supply Industry; Copenhagen Business School: Copenhagen, Denmark, 2016.

16. Stopford, M. Maritime Economics; Routledge: New York, NY, USA, 2013.

17. American Petroleum Institute; International Association of Oil \& Gas Producers. Sustainability Reporting Guidance for the Oil and Gas Industry. 2020. Available online: https://www.ipieca.org/media/5115/ipieca_sustainability-guide-2020.pdf (accessed on 19 November 2020).

18. Jære, L.; Norwegian Environment Agency. Environmental Impact of Oil and Gas Activities. BarentsWatch, 25 August 2016. Available online: https:/ / www.barentswatch.no/en/articles/Environmental-impact-of-oil-and-gas-activities/ (accessed on 19 November 2020).

19. Bech, C.; Rashidbeigi, S.; Roelofsen, O.; Speelman, E. The future is now: How oil and gas companies can decarbonize. McKinsey, 7 January 2020. Available online: https:/ / www.mckinsey.com/industries/oil-and-gas/our-insights/the-future-is-now-how-oiland-gas-companies-can-decarbonize (accessed on 21 November 2020).

20. Baden-Fuller, C.; Haefliger, S. Business models and technological innovation. Long Range Plan. 2013, 46, 419-426. [CrossRef]

21. Forbes-Cable, M.; Liu, W. Digital Disruption: Upstream Supply Chain Threats and Opportunities. Available online: https://www. woodmac.com/reports/upstream-oil-and-gas-digital-disruption-upstream-supply-chain-threats-and-opportunities-310260/ (accessed on 19 November 2020).

22. World Economic Forum and Accenture. Digital Transformation Initiative-Oil and Gas Industry. 2017. Available online: http: / / reports.weforum.org/digital-transformation (accessed on 19 November 2020).

23. Eglash, S.; Fisher, K. Sustainable Energy for All: Opportunities for the Oil and Gas Industry; Accenture: New York, NY, USA, 2012. 
24. Evans, S.; Vladimirova, D.; Holgado, M.; Van Fossen, K.; Yang, M.; Silva, E.A.; Barlow, C.Y. Business model innovation for sustainability: Towards a unified perspective for creation of sustainable business models. Bus. Strat. Environ. 2017, 26, 597-608. [CrossRef]

25. Florescu, M.S.; Ceptureanu, E.G.; Cruceru, A.F.; Ceptureanu, S.I. Sustainable supply chain management strategy influence on supply chain management functions in the oil and gas distribution industry. Energies 2019, 12, 1632. [CrossRef]

26. Al-Debei, M.M.; Avison, D. Developing a unified framework of the business model concept. Eur. J. Inf. Syst. 2010, 19, 359-376. [CrossRef]

27. Zott, A.; Aamit, R. The business model: Recent developments and future research. SSRN Electron. J. 2011, 37, 1019-1042. [CrossRef]

28. Bucherer, E.; Eisert, U.; Gassmann, O. Towards systematic business model innovation: Lessons from product innovation management. Creat. Innov. Manag. 2012, 21, 183-198. [CrossRef]

29. Veit, D.; Clemons, E.; Benlian, A.; Buxmann, P.; Hess, T.; Kundisch, D.; Leimeister, J.M.; Loos, P.; Spann, M. Business models: An information systems research agenda. Bus. Inf. Syst. Eng. 2014, 6, 45-53.

30. Arciszewski, T. Morphological analysis in inventive engineering. Technol. Forecast. Soc. Chang. 2018, 126, 92-101. [CrossRef]

31. Buzuku, S.; Farfan, J.; Harmaa, K.; Kraslawski, A.; Kässi, T. A case study of complex policy design: The systems engineering approach. Complexity 2019. [CrossRef]

32. Im, K.; Cho, H. A systematic approach for developing a new business model using morphological analysis and integrated fuzzy approach. Expert Syst. Appl. 2013, 40, 4463-4477. [CrossRef]

33. Kwon, M.; Lee, J.; Hong, Y.S. Product-service system business modelling methodology using morphological analysis. Sustainability 2019, 11, 1376. [CrossRef]

34. Zwicky, F. Discovery, Invention, Research through the Morphological Approach; MacMillan: New York, NY, USA, 1969.

35. Tukker, A. Eight types of product-service system: Eight ways to sutainability? Experiences from suspronet. Bus. Strateg. Environ. 2004, 260, 246-260. [CrossRef]

36. Kley, F.; Lerch, C.; Dallinger, D. New business models for electric cars-A holistic approach. Energy Policy 2011, 39, 3392-3403. [CrossRef]

37. Bocken, N.M.P.; Short, S.W.; Rana, P.; Evans, S. A literature and practice review to develop sustainable business model archetypes. J. Clean. Prod. 2014, 65, 42-56. [CrossRef]

38. Ahmad, N.K.W.; De Brito, M.P.; Rezaei, J.; Tavasszy, L.A. An integrative framework for sustainable supply chain management practices in the oil and gas industry. J. Environ. Plan. Manag. 2016, 60, 577-601. [CrossRef]

39. Gassmann, O.; Frankenberger, K.; Csik, M. The St. Gallen business model navigator. Int. J. Prod. Dev. 2013, 18, $249-273$.

40. Bouncken, R.B.; Kraus, S.; Roig-Tierno, N. Knowledge- and innovation-based business models for future growth: Digitalized business models and portfolio considerations. Rev. Manag. Sci. 2019, 20, 1-14. [CrossRef]

41. Osterwalder, A.; Pigneur, Y. Business Model Generation: A Handbook for Visionaries, Game Changers, and Challengers; John Wiley \& Sons: Hoboken, NJ, USA, 2010.

42. Chesbrough, H. The role of the business model in capturing value from innovation: Evidence from Xerox Corporation's technology spin-off companies. Ind. Corp Chang. 2002, 11, 529-555. [CrossRef]

43. Trott, P. Business Models. In Innovation Management and New Product Development, 6th ed.; Pearson: New York, NY, USA, 2017; pp. 412-444.

44. Chesbrough, H. Business model innovation: Opportunities and barriers. Long Range Plan. 2010, 43, 354-363. [CrossRef]

45. Morris, M.; Schindehutte, M.; Allen, J. The entrepreneur's business model: Toward a unified perspective. J. Bus. Res. 2005, 58, 726-735. [CrossRef]

46. Markides, C. Disruptive innovation: In need of better theory. J. Prod. Innov. Manag. 2006, 23, 19-25. [CrossRef]

47. Joyce, A.; Paquin, R.L. The triple layered business model canvas: A tool to design more sustainable business models. J. Clean. Prod. 2016, 135, 1474-1486. [CrossRef]

48. Ebneyamini, S.; Bandarian, R. Explaining the role of technology in the dynamics of the players business models in the global oil playground. Int. J. Energy Sect. Manag. 2019, 13, 556-572. [CrossRef]

49. Raut, R.D.; Narkhede, B.; Gardas, B.B. To identify the critical success factors of sustainable supply chain management practices in the context of oil and gas industries: ISM approach. Renew. Sustain. Energy Rev. 2017, 68, 33-47. [CrossRef]

50. Stevens, P. International Oil Companies; Chatham House: London, UK, 2016.

51. Gardas, B.B.; Raut, R.D.; Narkhede, B. Determinants of sustainable supply chain management: A case study from the oil and gas supply chain. Sustain. Prod. Consum. 2019, 17, 241-253. [CrossRef]

52. Wendel, D. Maritime Forecast to 2050; DNV-GL: Hovik, Norway, 2017; pp. 1-17.

53. Hassani, H.; Silva, E.S.; Al Kaabi, A.M. The role of innovation and technology in sustaining the petroleum and petrochemical industry. Technol. Forecast. Soc. Chang. 1027, 119, 1-17. [CrossRef]

54. Bengtsson, M.; Kock, S. "Coopetition" in Business Networks-To cooperate and compete simultaneously. Ind. Mark. Manag. 2000, $29,411-426$.

55. Cooper, M.C.; Lambert, D.M.; Pagh, J.D. Supply chain management: More than a new name for logistics. Int. J. Logist. Manag. 1997, 8, 1-14. [CrossRef] 
56. Squire, B.; Cousins, P.D.; Brown, S. Cooperation and knowledge transfer within buyer-supplier relationships: The moderating properties of trust, relationship duration and supplier performance. Br. J. Manag. 2009, 20, 461-477. [CrossRef]

57. Mackenzie, W. Upstream Supply Chain in Brief; Wood Mackenzie: Edinburgh, UK, 2019.

58. Martin, M.J.C. Managing Innovation and Entrepreneurship in Technology Based Firms; John Wiley and Sons Inc.: New York, NY, USA, 1994.

59. Bergman, L. Ways the Oil \& Gas Industry Is Trying to Become More Sustainable and Green. Biofriendly Planet, 7 March 2019. Available online: https:/ / biofriendlyplanet.com/eco-awareness/air-quality/emissions / ways-the-oil-gas-industry-is-tryingto-become-more-sustainable-and-green/ (accessed on 19 November 2020).

60. International Petroleum Industry Environmental Conservation Association. Exploring Low-Emissions Pathways for Transport. 2019. Available online: www.ipieca.org (accessed on 19 November 2020).

61. Albjerk, N.B.; Danielsen, T.K.; Krey, S. Operational Planning and Disruption Management in Offshore Logistics. Master's Thesis, Norwegian University of Science and Technology, Trondheim, Norway, 2015.

62. Borch, O.J.; Batalden, B.-M. Business-process management in high-turbulence environments: The case of the offshore service vessel industry. Marit. Policy Manag. 2014, 42, 481-498. [CrossRef]

63. Elhedhli, S.; Merrick, R. Green supply chain network design to reduce carbon emissions. Transp. Res. Part D Transp. Environ. 2012, 17, 370-379. [CrossRef]

64. Seuring, S.; Müller, M. From a literature review to a conceptual framework for sustainable supply chain management. J. Clean Prod. 2008, 16, 1699-1710. [CrossRef]

65. Wanasinghe, T.R.; Gosine, R.G.; James, L.A.; Mann, G.K.; De Silva, O.; Warrian, P.J. The Internet of things in the oil and gas industry: A systematic review. IEEE Internet Things J. 2020, 7, 8654-8673. [CrossRef]

66. Wanasinghe, T.R.; Wroblewski, L.; Petersen, B.K.; Gosine, R.G.; James, L.A.; De Silva, O.; Mann, G.K.; Warrian, P.J. Digital twin for the oil and gas industry: Overview, research trends, opportunities, and challenges. IEEE Access 2020, 8, 104175-104197. [CrossRef]

67. Ehret, M.; Wirtz, J. Unlocking value from machines: Business models and the industrial internet of things. J. Mark. Manag. 2017, 33, 111-130. [CrossRef]

68. Nguyen, T.; Gosine, R.G.; Warrian, P. A systematic review of big data analytics for oil and gas industry 4.0. IEEE Access 2020, 8, 61183-61201. [CrossRef]

69. West, B.; Lafferty, T. Synchronizing the offshore supply chain creates new value. Offshore 2008, 68, 78-81.

70. KonKraft. Project Competitiveness—Changing Tide on the Norwegian Continental Shelf; KonKraft: Oslo, Norway, 2018.

71. McKinsey. Supply Chain 4.0-The Next-Generation Digital Supply Chain. 2016. Available online: https://www.mckinsey. $\mathrm{com} /$ business-functions / operations/our-insights/supply-chain-40--the-next-generation-digital-supply-chain (accessed on 19 November 2020).

72. KonKraft. The Energy Industry of Tomorrow on the Norwegian Continental Shelf Climate Strategy towards and 2030-2050; KonKraft: Oslo, Norway, 2020.

73. Hall, A.D. Three-Dimensional Morphology of Systems Engineering. IEEE Trans. Syst. Sci. Cybern. 1969, 5, 156-160. [CrossRef] 